\title{
Toothpaste Activity Test of Laban Leaf Methanol Extract (Vitex pinnata) Against the Growth of Streptococcus mutans Bacteria
}

\author{
Cut Nuraskin $^{1 *}$, Reca Reca ${ }^{1}$, Teuku Salfiyadi ${ }^{1}$, Abdurrahman Abdurrahman $^{2}$, Teuku Iskandar Faisal $^{2}$, Cut Soraya $^{3}$ \\ ${ }^{1}$ Department of Dental Nursing, Polytechnic of Health, Ministry of Health, Aceh, Indonesia; ${ }^{2}$ Department of Nursing, Polytechnic \\ of Health, Ministry of Health, Aceh, Indonesia; ${ }^{3}$ Department of Dentistry, Universitas Syiah Kuala, Banda Aceh, Indonesia
}

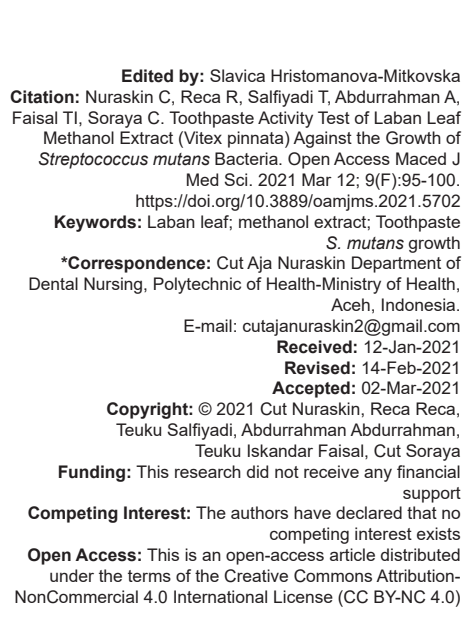

\section{Introduction}

Oral health is an integral part of general health. The oral cavity can be a manifestation of systemic disease and can be a sign of early disease [1]. Oral disease is a major global public health problem affecting more than 3.5 billion people [2]. The most common and globally influencing oral diseases are dental caries (tooth decay), periodontal disease, tooth loss, and lip and oral cavity cancer [3]. Tooth and mouth disease that is commonly found in the community is dental caries. Dental caries is the most common oral condition associated with biofilms that endangers millions of people's quality of life [4], [5]. Various attempts have been made to remove dental caries, such as removing dental plaque by mechanical methods [6]. Preventing and controlling dental caries are a big challenge. Over the centuries, many prophylactic agents have been used to prevent dental caries, such as antibiotics, compounds of plant and plant origin, mouthwashes, toothpaste, gels, varnishes, and caries vaccines [7]. The bacteria that play a role in plaque formation and caries development are Streptococcus mutans. S. mutans is a pioneer bacteria involved in dental caries [8]. S. mutans is the bacteria that most contribute to the incidence of dental caries because of their ability to produce acids that can lower the oral cavity's pH and cause tooth demineralization [9], [10].

One of the natural ingredients used as a substitute for preventing dental caries is the methanol extract of Laban leaves. Laban plants contain flavonoids, saponins, tannins, and polyphenols, known to have antibacterial properties [11]. At the same time, the compound extract from Laban has the potential to be antimicrobial, anti-inflammatory, antidiabetic, antioxidant, antitumor, antifungal, and antibacterial [12]. 
The ability of Laban plant extracts has traditionally been proven to treat diseases caused by pathogenic microorganisms. The community has much traditional knowledge using local biodiversity [13]. Herbal plant extracts have been used as antimicrobial agents in traditional medicine and have attracted considerable interest in preventing dental caries [14], [15]. The use of toothpaste containing fluoride has certain side effects, so it is necessary to find an alternative to toothpaste formulas made from natural ingredients. The addition of herbs to toothpaste is expected to inhibit plaque growth and reduce side effects caused by the addition of active fluoride substances, and this is related to the ability of several types of herbs to inhibit microbial growth [16]. Herbal toothpaste is very effective in reducing the degree of acidity and improving the oral cavity's $\mathrm{pH}$. A choice of antibacterial ingredients using herbal ingredients is needed [17]. Herbal toothpaste contains sodium bicarbonate, sodium fluoride, and herbal ingredients and has anti-inflammatory, natural antiseptic properties, stimulates an immune response, and has analgesic properties [18]. By killing or selectively inhibiting cariogenic bacteria in pathogenic dental plaque, non-pathological commensal microbial communities can be formed. Therefore, the purpose of this study was to test the activity of Laban leaf (Vitex pinata) methanol extract toothpaste against the growth of S. mutans bacteria?

\section{Methods}

This research used laboratory experimental (true experimental design) with post-test only control group design research location at the Poltekkes Pharmacy Laboratory of the Ministry of Health in Aceh in July-August. The research sample consisted of Laban leaves randomly collected from the le Seu Um Geothermal area of Selawah Agam Aceh Besar, Aceh province.

Samples and specimens have been identified as number 558/UN11.1.28.1/DT/2018 and stored in the Biology Department, Faculty of Mathematics and Natural Sciences, Syiah Kuala University. Tools used include glass (Pyrex), Autoclave (Vertical Type Autoclave), stirring rod, maceration container, Blender (Cosmos), Bunsen, Petri dish, porcelain cup, cover glass, hot plate, incubator, one needle, Laminar air flow, Mortar and pestle, analytical balance (CPA 6235 Sartorius), Horn spoon, Brookfield Viscometer, and Toothpaste container. The research materials used included Aquadest, S. mutans bacteria, Laban leaf methanol extract, glycerin, sterile cotton, calcium carbonate, menthol, sodium benzoate, sodium lauryl sulfate, sodium saccharin, $0.9 \% \mathrm{NaCl}$, and agar nutrients (NA).

\section{Research procedure}

Toothpaste Formulation of Laban Leaf Methanol Extract is shown in Table 1. Toothpaste formulations to be used with variations in concentrations.

Table 1: Toothpaste formulations to be used with variations in concentrations

\begin{tabular}{lllllll}
\hline \multirow{2}{*}{$\begin{array}{l}\text { Serial } \\
\text { number }\end{array}$} & Ingredient (\%) & Function & \multicolumn{4}{c}{ Dental pasta formula (\%) } \\
\cline { 3 - 7 } & & & F1 & F2 & F3 & F4 \\
\hline 1 & Laban extract ingredients & Active Ingredients & 1.5 & 3 & 4.5 & - \\
2 & Calcium carbonate & Abrasive material & 45 & 45 & 45 & 45 \\
3 & Glycerin & Humectant & 25 & 25 & 25 & 25 \\
4 & Na CMC & Binder & 1.5 & 1.5 & 1.5 & 1.5 \\
5 & Sodium Lauryl Sulfate & Surfactants & 1 & 1 & 1 & 1 \\
6 & Sodium Benzoate & Preservative & 0.1 & 0.1 & 0.1 & 0.1 \\
7 & Sodium Saccharin & Sweetener & 0.2 & 0.2 & 0.2 & 0.2 \\
8 & Menthol & Flavor & 0.2 & 0.2 & 0.2 & 0.2 \\
9 & Aquades & Solvent & 100 & 100 & 100 & 100 \\
\hline Na CMC: Sodium Carboxymethylcellulose. & & & & &
\end{tabular}

\section{Toothpaste making procedure}

Making toothpaste starts from sterilizing the tools, preparing the ingredients and tools, and weighing all the ingredients of the toothpaste formula. Preparation of a concentrated toothpaste formula, $1.5 \%, 3 \%$, and $4.5 \%$, Weigh the ingredients of calcium carbonate, glycerin, sodium carboxyl cellulose ( $\mathrm{Na} \mathrm{CMC})$, sodium laurel sulfate, sodium benzoate, sodium saccharin, menthol, and distilled water. Mass 1, Dissolve Na CMC in $25 \mathrm{ml}$ hot water, let stand for $15 \mathrm{~min}$ and stir until homogeneous. Grind the calcium carbonate and add the crushed sodium lauryl sulfate until homogeneous; put in mass 1 while grinding homogeneously. Dissolve the leaf extract with glycerin, then stir it homogeneously and put it in mass 1 while stirring until it is homogeneous. Dissolve sodium benzoate and sodium saccharin into the remaining water and stir until completely dissolved then enter into mass 1 until homogeneous in the form of a paste. Add menthol to the paste mass, crushed until homogeneous. Put the paste into the tube [19].

\section{Testing the physical-chemical quality of toothpaste organoleptic test}

Toothpaste preference test includes objectively observed shape, color, and aroma. The test was carried out every week for 3 weeks of storage (Afni et al., 2015). Homogeneity test homogeneity testing is done through toothpaste, which will be tested smeared on a glass object to observe homogeneity. If there are no coarse grains on the object-glass, the toothpaste tested is declared homogeneous, whereas if there are coarse grains, it shows that the toothpaste is not homogeneous. Testing was carried out every week for 3 weeks of storage [19].

Acidity test $(\mathrm{pH})$ toothpaste sample weighed $1 \mathrm{~g}$ with 30 distilled water. $\mathrm{PH}$ test measurements were carried out by dipping the $\mathrm{pH}$ meter into the paste preparation until it shows a constant number after a while. The $\mathrm{pH}$ value is obtained from this number. 
Testing was carried out every week for 3 weeks of storage [19].

\section{Foam forming test}

The toothpaste sample was weighed as much as $1 \mathrm{~g}$, put into a test tube, then added distilled water up to $10 \mathrm{ml}$, shaken by turning the test tube back and forth, then immediately measured the level of foam produced. The tube is then left to stand for $5 \mathrm{~min}$; then, the final foam height is measured again after $5 \mathrm{~min}$ [20]. The higher the foam stability value, the higher the quality of the foam produced. Foam stability is greatly influenced by particle size - the more and the larger the particle size, the foam stability decreases. The percentage of foam above $70 \%$ is said to be good because it can still keep the bubbles from bursting [21]. Antibacterial activity test of Laban leaf extract toothpaste preparation of $S$. mutans bacterial suspension preparation of the suspension by taking one dose of bacterial colonies, and dispensed in a solution of $0.9 \% \mathrm{NaCl}$ as much as $5 \mathrm{ml}$. The bacterial suspension was then homogenized with vortex until the turbidity was obtained according to the McFarland standard of $0.5(1.5 \times 108 \mathrm{CFU} / \mathrm{ml})$.

\section{Antibacterial test}

Preparation of five test tubes marked according to the concentration $(1.5 \%, 3 \%$, and $4.5 \%)$. Tube 1 is filled with $1 \mathrm{~g}$ of $1.5 \%$ concentration $\mathrm{F} 1$ toothpaste formula. Tube 2 (F2) with $3 \%$ concentration, tube 3 (F3) with $4.5 \%$ concentration, and tube 4 (F4) $1 \mathrm{~g}$ of toothpaste without extract as a negative control group, and tube 5 filled with $1 \mathrm{ml}$ Ciprofloxacin $10 \mu \mathrm{g} /$ $\mathrm{ml}$ as a positive control. Furthermore, all tubes were filled with $3.5 \mathrm{ml}$ Trypticase soy broth, and added $0.5 \mathrm{ml}$ of $S$. mutans bacteria which had been diluted with the serial dilution method using an Eppendorf pipette into each concentration tube $(1.5 \%, 3 \%$, and $4.5 \%)$, then homogenized using vortex [22]. Each $0.1 \mathrm{ml}$ tube was dropped on a plate that had been labeled according to the label on the concentration tube $(1.5 \%, 3 \%, 4.5 \%)$, and dripped onto the TYS20B medium by the scatter method, then put in a candle jar and incubated in an incubator for $48 \mathrm{~h}$ at $37^{\circ} \mathrm{C}$ with the anaerobic atmosphere [22]. Observations of the antibacterial effect were carried out after $48 \mathrm{~h}$ by counting the colonies that grew on the media with a colony counter. Petri dishes have a smaller number of bacterial colonies than the negative control group Petri dishes. Minimum Killing Concentration (KBM) of toothpaste is a Petri dish with no bacterial colony growth.

Data analysis was carried out descriptively. Antibacterial activity data were statistically processed with one-way ANOVA at a confidence level of $\alpha 0.05$.

\section{Results and Discussion}

\section{Organoleptic test}

Results in organoleptic test results observed for 3 weeks showed different toothpaste color and aroma results in various concentration formulations. The result is that there are differences in color and aroma; the higher the concentration of the resulting color, the darker it is, and produce a soft, sweet taste in the toothpaste of the methanol extract of Laban leaves (Table 2).

Table 2: Analysis of organeleptie test

\begin{tabular}{lllll}
\hline Formula (\%) & Oganoleptic & Observation & & \\
\cline { 3 - 5 } & & Week I & Week II & Week III \\
\hline F1 (1.5) & Color & Light green & Light green & Light green \\
& Aroma & Menthol & Menthl & Menthol \\
& Texture & Soft & Soft & Soft \\
& Taste & Sweet & Sweet & Sweet \\
F2 (3) & Color & Green & Green & Green \\
& Aroma & Menthol & Menhol & Menthol scent \\
& Texture & Soft & Soft & Soft \\
& Taste & Sweet & Sweet & Sweet \\
F3 (4.5) & Color & Dense moss green & Dense moss green & Dense moss green \\
& Aroma & Typical extract & Typical extract & Typical extract \\
& Texture & Soft & Soft & Soft \\
& Taste & Sweet & Sweet & Sweet \\
F4 control & Color & Beige & Beige & Beige \\
& Aroma & Menthol & Menthol & Menthol \\
& Texture & Soft & Soft & Soft \\
& Taste & Sweetness & Sweet & Sweet \\
\hline
\end{tabular}

\section{Homogeneity test}

Results the homogeneity test results produced by the toothpaste of Laban leaf methanol extract for all concentrations were homogeneous. Length of storage does not affect the homogeneity of toothpaste. This is done through toothpaste, which will be tested smeared on a glass object to observe its homogeneity.

The test results obtained for each concentration are homogeneous. If there are no coarse grains on the slide, the toothpaste tested is declared homogeneous. If there are coarse grains, it shows that the toothpaste is not homogeneous. Tests are carried out every week for 3 weeks of storage Table 3 .

Table 3: Toothpaste homogeneity test of Laban leaf methanol extract

\begin{tabular}{llll}
\hline Formula (\%) & \multicolumn{2}{l}{ Toothpaste homogeneity observation } \\
\cline { 2 - 4 } & Week I & Week II & Week III \\
\hline F1 (1.5) & Homogeneous & Homogeneous & Homogeneous \\
F2 (3) & Homogeneous & Homogeneous & Homogeneous \\
F3 (4.5) & Homogeneous & Homogeneous & Homogeneous \\
F4 (0) & Homogeneous & Homogeneous & Homogeneous \\
\hline
\end{tabular}

\section{Acidity test results $(p H)$}

The $\mathrm{pH}$ test measurement is done by dipping the $\mathrm{pH}$ meter into the paste preparation until it shows a constant number after a while. The $\mathrm{pH}$ value is obtained from this number; the test is carried out every week for 3 weeks of storage. The $\mathrm{pH}$ acidity test results showed an effect of storage time (the week I, week II, and week III) on toothpaste's pH value. Based on the concentration of the highest $\mathrm{pH}$ value in the sequence, 
namely, F1 (1.5\%), F2 (3\%), and F3 (4.5\%), and F $4(0 \%)$, and has values of F1 8.76, F2 8.74, F3 8.6, and F4 8.67, but still, the normal limit of toothpaste is presented in Table 4

Table 4: $\mathrm{pH}$ test results of Laban leaf methanol extract

\begin{tabular}{lllll}
\hline Formula (\%) & \multicolumn{2}{l}{$\begin{array}{l}\text { Observation of the } \mathrm{pH} \text { of Laban leaf methanol } \\
\text { extract toothpaste }\end{array}$} & $\begin{array}{l}\text { Average amount } \\
\text { PH meter }\end{array}$ \\
\cline { 2 - 3 } & Week I & Week II & Week III & \\
\hline F1 (1.5) & 8.67 & 8.73 & 8.89 & 8.76 \\
F2 (3) & 8.59 & 8.81 & 8.83 & 8.74 \\
F3 (4.5) & 8.30 & 8.74 & 8.76 & 8.6 \\
F4 (0) & 8.93 & 8.98 & 9.16 & 8.67 \\
\hline
\end{tabular}

Foam formation test results toothpaste sample weighed as much as $1 \mathrm{~g}$ put in a test tube. Then, add distilled water until $10 \mathrm{ml}$ was shaken by turning the measuring test tube upside down until foamy. The tube was left to stand for $5 \mathrm{~min}$, and then measured the foam height. The foam formation test results for each concentration; the longer the foam formation is stored, the more it increases at all toothpaste concentrations [22]. The higher the foam stability value, the higher the quality of the foam produced. Foam stability is greatly influenced by particle size - the more the particle size, the lower the foam stability. The percentage of foam above $70 \%$ is good because it can still keep the bubbles from bursting (Asti, 2015).

Preferred test results toothpaste of Laban leaf methanol extract formula F2. About 3\% is the best formula that most panelists like. The toothpaste of the Laban leaf methanol extract formula 2 had the highest value, namely 14.75 , followed by formula 1 , formula 4 , formula 3, and formula 2, which was the best favored by the panelists based on the SPSS test. From the results of the output Table 5 , it can be seen that $p=0.000$, where $p(0.000)<\alpha(0.05)$. This means that there is an effect of formula (formula 1 , formula 2 , formula 3 , and formula 4 ) on the toothpaste preference test. Furthermore, which follow-up test has more influence between the formulas. The results above show that formula 2 has the highest value, namely 14.75 , followed by formula 1 , formula 4 , and formula 3 .

\section{Viscosity test results}

The viscosity test aims to determine how thick the toothpaste is produced, where the viscosity value states the strength of a liquid to flow. Different concentrations of active ingredients affect the viscosity value of the four toothpaste formulas made. The higher the active ingredient concentration, the greater the viscosity value. Na.CMC works through the development process by trapping or binding the existing water so that the water molecules will be close together, and an attractive force occurs.

Using Spindle Lv. 3 Speed 100 ppm.

Based Table 7 shows that the combination toothpaste formula of Laban leaf methanol extract has met the SNI 12-524-1995 standards regarding toothpaste. Toothpaste formula F3. $4.5 \%$ has the greatest viscosity, ranging from 241.0 (PDAs), and followed by F2. 240.4\%, and F1. 237.6\%. The higher the active ingredient concentration, the greater the viscosity value. SNI toothpaste's viscosity value (123524-1995) ranges from 200 to 500 . The measurement of the dispersibility of the toothpaste gel of methanol extract of Laban leaves is presented in Table 8. The dispersion test of the gel preparation was intended to determine the dispersibility of the paste when applied. The dispersibility is an important characteristic in paste formulas. From the measurement of the dispersive power diameter, the preparation of the F4 toothpaste formula did not meet the dispersion requirements of 5-7 cm [23].

Based on Table 8, it can be seen that $p=0.001$, $p=(0.001)<\alpha(0.05)$ then rejects $\mathrm{HO}$. This means that there is an effect of formula (F1 [1.5\%], F2 [3\%], F3 [4.5\%], and F4 [0\%]) and time (the week I, week II, and week III) on the spreadability of toothpaste. A further test that is more influential between the formulas can be seen that formula $3(4.5 \%)$, formula $1(1.5 \%)$, and formula $2(3 \%)$ and have the highest value, respectively, namely, 5.7400, 5.3700, and 5.3467 which are in the same subset. Meanwhile, F4 $(0 \%)$ is the lowest.

\section{Test the qualitative content of the metal}

After a qualitative test, the content of specific heavy metal $\mathrm{Pb}$ was carried out on the toothpaste formula sample of Laban leaf methanol extract at the Chemical Laboratory of Pharmacy, Syiah Kuala University. The results are shown in Table 9. The metal qualitative testing procedure by inserting $5 \mathrm{ml}$ of sample into a test tube, add $1 \mathrm{ml}$ of $10 \% \mathrm{w} / \mathrm{v}$ Na2S solution (weight per volume), shake, and observe. If turbidity occurs, it means that it contains metal. Qualitative analysis $(\mathrm{Pb})$, put $5 \mathrm{ml}$ of sample in a test tube, with the addition of $1 \mathrm{~N} \mathrm{NH} 4 \mathrm{OH}$, add $\mathrm{KCN}$ crystals, add $5 \mathrm{ml}$ of dithizone $0.005 \% \mathrm{w} / \mathrm{v}$ solution, shake strongly, let the layers separate, then observe, if a dark red color is formed it means the sample containing $\mathrm{Pb}$ [24]. Based on Table 9, it can be seen that the toothpaste formulas

Table 5: Toothpaste foam formation of Laban leaf methanol extract

\begin{tabular}{|c|c|c|c|c|c|c|c|c|c|}
\hline \multirow[t]{3}{*}{ Formula (\%) } & \multicolumn{9}{|c|}{ Observation of foam formation } \\
\hline & \multicolumn{3}{|l|}{ Week I } & \multicolumn{3}{|l|}{ Week II } & \multicolumn{3}{|l|}{ Week II } \\
\hline & Initial foam & Final foam & Percentage & Initial foam & Final foam & Percentage & Initial foam & Final foam & Percentage \\
\hline F1 (1.5) & 8 & 7.5 & 93.75 & 7.9 & 7.5 & 94.93 & 7.3 & 7 & 95,89 \\
\hline F2 (3) & 8.6 & 8 & 93.02 & 7.5 & 7 & 93.33 & & 6.8 & 97.14 \\
\hline F3 (4.5) & 9.3 & 8.8 & 9.623 & 8.7 & 8.3 & 95.40 & 8.7 & 8.5 & 97.70 \\
\hline F4 & 7.3 & 7 & 95.890 & 7 & 6.5 & 92.85 & 7.3 & 7.1 & 96.55 \\
\hline
\end{tabular}


F4 (0\%), F3 (4.5\%), F2 (3\%), and F1 (1.5\%) do not contain $\mathrm{Pb}$ metal quality.

Table 6: Laban leaf extract toothpaste preferred test

\begin{tabular}{llllll}
\hline Formula & $\mathrm{n}$ & \multicolumn{5}{l}{ Subset for alpha $=0.05$} \\
\cline { 3 - 6 } & & 1 & 2 & 3 & 4 \\
\hline Formula 3 & 4 & 3.00 & 5.25 & & \\
Formula 4 & 4 & & & 7.00 & \\
Formula 1 & 4 & & & 1.000 & 1.000 \\
Formula 2 & 4 & 1.000 & 1.000 & 1.000 \\
Significant & & &
\end{tabular}

\section{Results of antibacterial activity test of Laban leaf extract toothpaste}

Results of bacterial culture and Gram stain the $S$. mutans bacteria used in this study were pure cultures from the Microbiology Laboratory of the Faculty of Veterinary Medicine, Syiah Kuala University, Banda Aceh, which were then cultured on TYS20B media and then incubated for $48 \mathrm{~h}$ at $37^{\circ} \mathrm{C}$. Table 7: Toothpaste viscosity value of Laban leaf methanol extract

\begin{tabular}{lll}
\hline Serial number & Sample (\%) & Visitations (Cp) \\
\hline 1 & Fo & 24.3 \\
2 & 1.5 & 237.6 \\
3 & 3 & 240.4 \\
4 & 4.5 & 241.0 \\
\hline Using spindle Lv. 3 Speed 100 ppm. & &
\end{tabular}

The results of bacterial culture showed round colonies that were growing on the surface of the media. Before the inhibitory test is carried out, Gram staining is first carried out to ensure that the bacteria tested are $S$. mutans bacteria. Table 8: Spreadability of Laban leaf methanol extract toothpaste

\begin{tabular}{lllll}
\hline Formula (\%) & \multicolumn{3}{l}{ Scatter diameter $(\mathrm{cm})$ with a load of 50 $\mathrm{g}$} & \multirow{2}{l}{$\begin{array}{l}\text { Total average } \\
\text { dispersive power }(\mathrm{cm})\end{array}$} \\
\cline { 2 - 4 } & Week I & Week II & Week III & dis. \\
\hline F1 (1.5) & 5.13 & 5.46 & 5.52 & 5.37 \\
F2 (3) & 5.13 & 5.35 & 5.56 & 5.34 \\
F3 (4.5) & 5.82 & 5.57 & 5.83 & 5.74 \\
F4 (0) & 4.61 & 4.82 & 4.71 & 4.71 \\
\hline
\end{tabular}

The Gram staining results under the microscope show that bacteria are round, colonized, form paired chains, and purple.

Table 9: Results of the $\mathrm{Pb}$ metal quality content

\begin{tabular}{llll}
\hline $\begin{array}{l}\text { Formula } \\
(\%)\end{array}$ & \multicolumn{2}{l}{ The results of the Pb lead analysis } & \\
\cline { 2 - 4 } & Sample weight $(\mathrm{g}) / 50 \mathrm{ml}$ solvent & Results of lead analysis $(\mathrm{Pb})$ & Analysis method \\
\hline $\mathrm{F} 1(1.5)$ & 1.1258 & - & AAS \\
$\mathrm{F} 2(3)$ & 1.1650 & - & \\
$\mathrm{F} 3(4.5)$ & 1.1257 & - & \\
$\mathrm{F} 4(0)$ & 1.0396 & - & \\
\hline
\end{tabular}

\section{Multilevel dilution}

The result of stratified dilution from $S$. mutans suspension is shown in Table 10. Number of colonies of S. mutants as result of multilevel dilution.

Table 10: Number of colonies of Streptococcus mutants as a result of multilevel dilution

\begin{tabular}{ll}
\hline Dilution rate & Colony growth rates colonies/Petri dishes \\
\hline $10^{-1}$ & 1062 \\
$10^{-2}$ & 1012 \\
$10^{-3}$ & 816 \\
$10^{-4}$ & 640 \\
$10^{-5}$ & 408 \\
$10^{-6}$ & 209 \\
$10^{-7}$ & 114 \\
$10^{-8}$ & 86 \\
\hline
\end{tabular}

Based on the results in Table 10, it is known that the $7^{\text {th }}$ dilution (10-7) has a colony number of 114 . This level of dilution is feasible to be chosen for sample testing because it meets the colony requirements of 30-300 CFU/plate.

Results of the test for antibacterial activity of methanol extract of Laban leaves on the growth of S. mutans

The activity of the methanol extract of Laban leaves on S. mutans was carried out two repetitions. The average number of $S$. mutans colonies after testing showed the most colony growth in the negative control group $\left(1.274 \times 10^{-7} \mathrm{CFU} / \mathrm{mL}\right)$, and the least was at a concentration of $4.5 \%\left(108.5 \times 10^{-7} \mathrm{CFU} / \mathrm{mL}\right)$. The number of bacterial colonies also seen to decrease at the increase in the concentration is presented in Table 11.

Table 11: Number of colonies

\begin{tabular}{llll}
\hline Concentration of test material & \multicolumn{2}{c}{ Number of S. mutans colonies } & \multirow{2}{*}{$\begin{array}{l}\text { Average number of } \\
\text { colonies (CFU/ml) }\end{array}$} \\
\cline { 2 - 3 } & Repetition I & Repetition II & $634.5 \times 10^{-7}$ \\
\hline $1.5 \%$ & $671 \times 10^{-7}$ & $598 \times 10^{-7}$ & \\
$3 \%$ & $434 \times 10^{-7}$ & $420 \times 10^{-7}$ & $427 \times 10^{-7}$ \\
$4.5 \%$ & $117 \times 10^{-7}$ & $100 \times 10^{-7}$ & $108.5 \times 10^{-7}$ \\
$\begin{array}{l}\text { Positive control - toothpaste } \\
\text { without extract }\end{array}$ & $1260 \times 10^{-7}$ & $1288 \times 10^{-7}$ & $1.274 \times 10^{-7}$ \\
$\begin{array}{l}\text { Negative control } \\
\text { Ciprofloxacin } 10 \mathrm{\mu g} / \mathrm{ml}\end{array}$ & $0 \times 10^{-7}$ & $2 \times 10^{-7}$ & $1 \times 10^{-7}$ \\
\hline
\end{tabular}

The average number of $S$. mutans colonies after testing showed the most colony growth in the negative control group $\left(1.274 \times 10^{-7} \mathrm{CFU} / \mathrm{mL}\right)$, and the least was at a concentration of $4.5 \%\left(108.5 \times 10^{-7} \mathrm{CFU} / \mathrm{mL}\right)$. The minimum inhibitory concentration (MIC) of Laban leaf methanol extract toothpaste against $S$. mutans growth was aimed at a concentration of $4.5 \%$, with an average number of bacterial colonies $108.5 \times 10^{-7}$. In this study, there was no minimum killing concentration (KBM). The statistical test used in this study is one-way ANOVA which has the requirements of more than two groups; the distribution and homogeneity of the data variants are the same. This study had five groups, consisting of three treatment groups, $1.5 \%, 3 \%$, and $4.5 \%$, and two control groups, toothpaste without extracts negative control group and Ciprofloxacin $10 \mu \mathrm{g} / \mathrm{ml}$ positive control. The test results are based on the ANOVA concentration, the significance value $(0.000)<0.05$, there is a difference in the number of bacterial colonies based on the concentration variable. ANOVA test results based on the repetition of significant values $(0.423)>0.05$ then accept $\mathrm{H}_{0}$. This means that all repetitions have the same effect on the number of colonies so that there is no difference in the number of colonies based on the repetition variable. The MIC of toothpaste with the methanol extract of Laban leaves against the growth of $S$. mutans was aimed at a concentration of $4.5 \%$, and no minimum kill concentration (MBC) was found in this study. 


\section{Conclusion}

MIC toothpaste extract of Laban leaf methanol against $S$. mutans growth was aimed at a concentration of $4.5 \%$, with an average number of bacterial colonies $\left(108.5 \times 10^{-7} \mathrm{CFU} / \mathrm{mL}\right)$. ANOVA test results based on the concentration of significance value $(0.000)<0.05$, there is a difference in the number of bacterial colonies based on the concentration variable. ANOVA test results based on the repetition of significant values $(0.423)>0.05$, which means that all repetitions have the same effect on the number of colonies, so there is no difference in the number of colonies based on the repetition variable.

\section{References}

1. Casamassimo PS, Flaitz CM, Hammersmith K, Sangvai S, Kumar A. Recognizing the relationship between disorders in the oral cavity and systemic disease. Pediatr Clin North Am. 2018;65(5):1007-1032. https://doi:10.1016/j.pcl.2018.05.009 PMid:30213346

2. Watt RG, Daly B, Allison P, Macpherson LM, Venturelli R, Listl S, et al. Ending the neglect of global oral health: Time for radical action. Lancet. 2019;394(10194):261-72. https://doi:10.1016/ S0140-6736(19)31133-X

PMid:31327370

3. Peres MA, Macpherson LM, Weyant RJ, Daly B, Venturelli R, Mathur MR, et al. Oral diseases: A global public health challenge. Lancet. 2019;394(10194):249-60. https://doi:10.1016/ S0140-6736(19)31146-8

PMid:31327369

4. Marcenes W, Kassebaum NJ, Bernabé E, Flaxman A, Naghavi M, Lopez A, et al. Global burden of oral conditions in 1990-2010: A systematic analysis. J Dent Res. 2013;92(7):5927. https://doi:10.1177/0022034513490168 PMid:23720570

5. Kassebaum NJ, Bernabé E, Dahiya M, Bhandari B, Murray CJ Marcenes W. Global burden of untreated caries: A systematic review and metaregression. J Dent Res. 2015;94(5):650-8. https://doi:10.1177/0022034515573272

PMid:25740856

6. Porto TS, Rangel R, Furtado NA, de Carvalho TC, Martins $\mathrm{CH}$, Veneziani RC, et al. Pimarane-type diterpenes: Antimicrobial activity against oral pathogens. Molecules. 2009;14(1):191-9. https://doi:10.3390/molecules14010191

PMid:19127247

7. Greenberg M, Dodds M, Tian M. Naturally occurring phenolic antibacterial compounds show effectiveness against oral bacteria by a quantitative structure-activity relationship study. J Agric Food Chem. 2008;56(23):11151-6. https://doi:10.1021/jf8020859 PMid:19007234

8. Ravi SB, Nirupad S, Chippagiri P, Pandurangappa R. Antibacterial effects of natural herbal extracts on Streptococcus mutans: Can they be potential additives in dentifrices? Int J Dent. 2017;2017:4921614. https://doi:10.1155/2017/4921614 PMid:29201054

9. Kreth J, Zhang Y, Herzberg MC. Streptococcal antagonism in oral biofilms: Streptococcus sanguinis and Streptococcus gordonii interference with Streptococcus mutans. J Bacteriol. 2008;190(13):4632-40. https://doi.org/10.1128/JB.00276-08 PMid: 18441055

10. Liu C, Worthington RJ, Melander $\mathrm{C}$, Wu H. A new small molecule specifically inhibits the cariogenic bacterium Streptococcus mutans in multispecies biofilms. Antimicrob Agents Chemother. 2011;55(6):2679-87. https://doi.org/doi:10.1128/AAC.01496-10 PMid:21402858

11. Goh MP, Basri AM, Yasin H, Taha H, Ahmad N. Ethnobotanical review and pharmacological properties of selected medicinal plants in Brunei Darussalam: Litsea elliptica, Dillenia suffruticosa, Dillenia excelsa, Aidia racemosa, Vitex pinnata and Senna alata. Asian Pac J Trop Biomed. 2017;7(2):173-80. https://doi.org/10.1016/j.apjtb.2016.11.026

12. Subasini TU. Morpho-anatomikal and physicochemical evaluation of Vitex pinnata leaves. Eur J Biomed Pharm Sci 2016;3:191-201.

13. Pradhan, B. K., \& Badola, H. K. Ethnomedicinal plant use by Lepcha tribe of Dzongu valley, bordering Khangchendzonga Biosphere Reserve, in north Sikkim, India. Journal of Ethnobiology and Ethnomedicine. 2008;4,1-18. https:// doi:10.1186/1746-4269-4-22 PMid:18826658

14. Song JH, Yang TC, Chang KW, Han SK, Yi HK, Jeon JG. In vitro effects of a fraction separated from Polygonum cuspidatum root on the viability, in suspension and biofilms, and biofilm formation of mutans streptococci. J Ethnopharmacol. 2007;112(3):419-25. https://doi:10.1016/j.jep.2007.03.036

PMid: 17543483

15. Sampaio FC, Pereira Mdo S, Dias CS, Costa VC, Conde NC Buzalaf MA. In vitro antimicrobial activity of Caesalpinia ferrea Martius fruits against oral pathogens. J Ethnopharmacol. 2009;124(2):289-94. https://doi:10.1016/j.jep.2009.04.034 PMid:19397986

16. Sasmita IS, Pertiwi AS, Halim M. Gambaran efek pasta gig yang mengandung herbal terhadap penurunan indeks plak. Dent J. 2006;2(8):1-11.

17. Khairnar MR, Dodamani AS, Karibasappa GN, Naik RG Deshmukh MA. Efficacy of herbal toothpastes on salivary $\mathrm{pH}$ and salivary glucose a preliminary study. J Ayurveda Integr Med. 2017;8(1):3-6. https://doi:10.1016/j.jaim.2016.12.004 PMid:28298260

18. Rahmah RY, Rachmadi P, Widodo. Perbandingan Efektivitas Pasta Gigi Herbal Dengan Pasta Gigi Non Herbal Terhadap Penurunan Indeks Plak Pada Siswa SDN Angsau 4 Pelaihari. Dentino (Jur. Ked. Gigi). 2014;2:120-4.

19. Afni N, Said N, Yuliet. Test the antibacterial activity of toothpaste betel nut (Areca catechu L.) seed extract against Streptococcus mutans and Staphylococcus aureus. GALENIKA J Pharm. 2015;2442-8744:48-58.

20. Sari R. Testing the antibacterial activity of liquid soap from the extract aloe vera leaf bark. Pharm Sci Res. 2018;4:111-20.

21. Nauli AP, Darmanto YS, Susanto E. Characteristics of liquid soap with the addition of different seawater fish collagen. $J$ Fishery Product Biotechnol Processing. 2015;4:1-6.

22. Widarsih E, Mahdalin A, Harismah K. Formulation of Betel Leaf Toothpaste (Piper betle L.) with Natural Sweetener Stevia Leaf Extract (Stevia rebaudiana). URECOL. 2017; 157-162.

23. Warnida H, Juliannor A, Sukawaty Y. Gel toothpaste formulations Dayak (Eleutherine bulbosa (Mill.) Urb.) ethanol extract. J Clinical Farm Science. 2016;3:42-49.

24. Saputro A. Identifikasi Kualitatif Kandungan Logam Berat ( $\mathrm{Pb}, \mathrm{Cd}, \mathrm{Cu}$, Dan Zn) Pada Ikan Sapu-Sapu (Hypostomus plecostomus) Di Sungai Pabelan Kartasura Tahun 2012 (Doctoral Dissertation. Surakarta: Universitas Muhammadiyah Surakarta; 2012. 